\title{
Adiponectin is secreted by theca layer cells isolated from chicken ovarian follicles
}

\author{
Jill A Hadley, Olga Ocón-Grove and Ramesh Ramachandran \\ Center for Reproductive Biology and Health, Department of Animal Science, The Pennsylvania State University, \\ University Park, Pennsy/vania, USA \\ Correspondence should be addressed to R Ramachandran; Email: RameshR@psu.edu
}

\begin{abstract}
Adiponectin, an adipokine hormone, influences glucose utilization, insulin sensitivity and energy homeostasis by signaling through two distinct receptors, ADIPOR1 and ADIPOR2. We previously reported that adiponectin and its receptors are expressed in several organs, including testes in chicken. We report herein that adiponectin gene is expressed exclusively in theca layer while ADIPOR1 and $A D I P O R 2$ genes are expressed in granulosa and theca layers of all preovulatory and prehierarchical follicles of the chicken ovary. Estradiol and/or progesterone treatment of sexually immature chickens significantly altered expression of adiponectin and ADIPOR1 in the ovary. Using anti-chicken adiponectin-, ADIPOR1-, or ADIPOR2- antibodies, adiponectin-immunoreactive (ir) cells were found exclusively in the theca layer, and ADIPOR1-ir and ADIPOR2-ir cells were found both in theca and granulosa layers. Theca layer cells dispersed from preovulatory and prehierarchical follicles were found to synthesize and secrete a $720 \mathrm{kDa}$ heavy molecular weight (HMW) isoform of adiponectin in vitro. Recombinant chicken adiponectin (rcADN) expressed in eukaryotic cells under serum-free conditions comprised primarily of the HMW isoform. Treatment of granulosa cells dispersed from 9 to $12 \mathrm{~mm}$ preovulatory follicle and 6 to $8 \mathrm{~mm}$ prehierarchical follicle with rcADN or an adiponectin receptor agonist, adipoRon, increased pERK and pACC abundance. In addition, both rcADN and adipoRon were found to significantly decrease the expression of steroidogenic acute regulatory protein gene expression in granulosa cells of preovulatory and prehierarchical follicles. In conclusion, adiponectin secreted by theca cell layer is identical in mass to circulating adiponectin. Systemic and/or theca-derived adiponectin is likely to affect proliferation, metabolism, and steroidogenesis of ovarian follicular cells.

Reproduction (2020) 159 275-288
\end{abstract}

\section{Introduction}

Adiponectin, an adipokine, is the most abundantly expressed protein in adipose tissue and also is the most abundant hormone in circulation (Arita et al. 1999). Adiponectin stimulates two distinct transmembrane receptors, ADIPOR1 and ADIPOR2, that are ubiquitously expressed throughout the body, including the reproductive system. Some of the beneficial effects of adiponectin include improved cellular glucose utilization, increased insulin sensitivity, decreased hepatic gluconeogenesis, and fatty acid oxidation, thereby influencing metabolism and energy homeostasis. During its synthesis in adipocytes, the $30 \mathrm{kDa}$ monomeric adiponectin undergoes extensive post-translational modifications, and multimerization resulting in secretion of three distinct adiponectin isoforms: low $(67 \mathrm{kDa}$ LMW), medium (136 kDa; MMW), and heavy (300 kDa; HMW) molecular weight adiponectin (Tsao et al. 2002, 2003, Waki et al. 2003). We found that adiponectin in chicken plasma and adipose tissue is predominantly composed of a unique multimeric HMW isoform that is larger than $669 \mathrm{kDa}$ mass (Hendricks et al. 2009).
A mass spectrometric analysis revealed that chicken adiponectin contains a greater number of lysine residues in the collagenous domain compared to human adiponectin, potentially responsible for multimerization and formation of a stable unique HMW adiponectin isoform (Hendricks et al. 2009).

In addition to adipose tissue, adiponectin and its receptors are expressed in multiple tissues (Maddineni etal. 2005, Ramachandran etal. 2007, OconGrove et al. 2008). In the chicken ovary, the adiponectin gene was found to be mainly expressed in theca layers and is suggested to exert paracrine or autocrine effects on ovarian steroidogenesis (Chabrolle et al. 2007a). We found that the surface epithelial cells isolated from the chicken ovary and ascites-derived ovarian cancer cells isolated from the chicken model of ovarian cancer were found to express adiponectin and its receptors (Tiwari et al. 2015). Adiponectin-null mice are subfertile due to disrupted estrous cycle and impaired folliculogenesis associated with lower serum estradiol and FSH levels (Cheng et al. 2016). Adiponectin HMW isoform is selectively reduced in women with polycystic ovarian syndrome independent of $\mathrm{BMI}$ and insulin 
resistance (Aroda et al. 2008, O'Connor et al. 2010). Adiponectin levels were less abundant in follicular fluid and ADIPOR1 expression in granulosa cells was lesser in obese women compared to normal weight subjects (Bongrani et al. 2019). Collectively, adiponectin appears to play a critical role in regulating the female reproductive system.

Whereas the adiponectin gene expression in ovarian follicles has been well documented in several species, the secretion of adiponectin from ovarian follicular cells and multimeric composition of ovarian adiponectin remains unknown. We hypothesized that theca layer cells isolated from the chicken ovarian follicles secrete an HMW isoform of adiponectin when cultured in vitro. The main objectives of the present study are (i) to characterize expression of adiponectin and its receptors in the ovarian follicles, (ii) to determine the extent to which gonadal steroids alter the expression of ovarian adiponectin and its receptors, (iii) to determine if theca layer cells secrete adiponectin, and (iv) to determine if chicken-specific adiponectin affects critical signal transduction events within granulosa cells.

\section{Materials and methods}

\section{Animals}

All animal procedures were approved by the Pennsylvania State University's Institutional Animal Care and Use Committee. Broiler breeder (Cobb 500) and leghorn (Hy-Line W36) chickens were provided a photoperiod of $16 \mathrm{~h}$ light: $8 \mathrm{~h}$ dark unless otherwise noted. Broiler breeder hens were maintained on a restricted feeding regimen recommended by the Cobb 500 Breeder Management Guide. Leghorn hens were allowed access to feed and water ad libitum at all times.

\section{Expression of adiponectin, ADIPOR1, and ADIPOR2 mRNA in ovarian follicles}

Leghorn (35 weeks old; $n=6$ ) or broiler breeder chickens (3055 weeks old; $n=6$ ) were killed to collect the ovary. Ovarian follicles were separated into F1-F4, 9-12 mm, and 6-8 mm follicles. The granulosa and theca cell layers from each follicle were separated as described previously (Krzysik-Walker et al. 2007, Maddineni et al. 2008). Total RNA from granulosa and thecal layers was extracted using Trizol (Invitrogen) and/or the RNeasy kit (Qiagen). The quality and quantity of RNA was evaluated using a spectrophotometer (Nanodrop, Wilmington, DE, USA). Following on-column DNAse-I (Qiagen) treatment, first-strand cDNA was synthesized by reverse transcribing 1 $\mu \mathrm{g}$ of total RNA using random hexamers (Promega), $1 \mathrm{mM}$ dNTP mixture, (Promega), 2U M-MLV reverse transcriptase (New England BioLabs, Beverly, MA, USA), and $1 \mu \mathrm{L}$ RNAse inhibitor (Invitrogen) in $20 \mu \mathrm{L}$ volume. A touch-down PCR was performed as described previously (Maddineni et al. 2005, Ramachandran et al. 2007) to amplify adiponectin, ADIPOR1, and ADIPOR2 using primers listed in Supplementary Table 1 (see section on supplementary materials given at the end of this article). The PCR products were subjected to agarose gel electrophoresis and ethidium bromide staining. For negative controls, RT reactions without reverse transcriptase (-RT) were used in place of cDNA.

\section{Relative abundance of adiponectin, ADIPOR1, and ADIPO2 mRNA in ovarian follicles}

A real-time quantitative PCR ( $\mathrm{PPCR}$ ) was performed using cDNA prepared from F1, F3, 9-12 $\mathrm{mm}$ and $6-8 \mathrm{~mm}$ follicular total RNA ( $n=6$ leghorn hens) for determination of adiponectin-, ADIPOR1-, ADIPOR2-, $\beta$-actin-mRNA abundance as described previously (Maddineni et al. 2005, Ramachandran et al. 2007). Each reaction was done in triplicate using $100 \mathrm{ng}$ CDNA, 1× Platinum SYBR Green qPCR Super Mix-UDG (Invitrogen), and $300 \mathrm{nM}$ forward and reverse primers (Supplementary Table 1). Average critical log-linear threshold $\left(C_{T}\right)$ values for adiponectin, $A D I P O R 1$, and $A D I P O R 2$ were expressed as a proportion of $\beta$-actin mRNA $C_{\mathrm{T}}$ values following $2^{-\Delta \Delta \mathrm{Ct}}$ method (Livak \& Schmittgen 2001) and analyzed.

\section{Effect of gonadal steroids on ovarian adiponectin, ADIPOR1, and ADIPOR2}

Sexually immature leghorn chickens (16 weeks old; $n=7$ ) were maintained at $8 \mathrm{~h}$ light:16 $\mathrm{h}$ dark photoperiod. They were injected, intramuscularly, with peanut oil containing estradiol-17 $\beta\left(\mathrm{E}_{2} ; 0.5 \mathrm{mg} / \mathrm{kg}\right.$ body weight; 4 injections on alternate days (Dunn et al. 2003)), progesterone $\left(\mathrm{P}_{4} ; 0.17\right.$ $\mathrm{mg} / \mathrm{kg}$ body weight/day for 7 consecutive days (Liu \& Bacon 2005)), $E_{2}$ and $P_{4}$ together at the above dosage, or no steroids (negative control). Seven days after the first dose, chickens were killed to collect ovary and oviduct (infundibulum to shell gland). Total RNA was extracted from the ovary using Trizol (Invitrogen) and RNeasy kit (Qiagen). The quality and quantity of purified RNA were evaluated using a spectrophotometer (Nanodrop) and subjected to RT and qPCR for determination of adiponectin, $A D I P O R 1$, and ADIPOR2 mRNA abundance as described above.

\section{Immunohistochemical detection of ovarian adiponectin, ADIPOR1, or ADIPOR2}

Broiler breeder hen $(n=6)$ and leghorn hen $(n=6)$ ovarian stroma were fixed in Bouin's solution. The tissue was dehydrated and infiltrated with paraffin to prepare thin slices $(4 \mu \mathrm{m})$. The tissue sections were deparaffinized, hydrated, and rinsed in Tris-buffered saline ( $\mathrm{pH} \mathrm{7.4;} \mathrm{TBS).} \mathrm{Following} \mathrm{a} \mathrm{rinse} \mathrm{in} \mathrm{TBS}$ containing $0.1 \%$ Triton X-100 (TBSX), slides were treated with $1 \%$ goat serum and incubated overnight at $4{ }^{\circ} \mathrm{C}$ with custom generated $10 \mu \mathrm{g} / \mathrm{mL}$ affinity-purified rabbit anti-chicken adiponectin (Hendricks et al. 2009), anti-chicken ADIPOR1, or anti-chicken ADIPOR2 antibodies (Ocon-Grove et al. 2008). Specificity of all three antibodies for immunodetection of adiponectin, ADIPOR1, and ADIPOR2 has been validated previously by pre-adsorbing the antibodies with respective peptides used for generating the antibody and testing them in Western blotting and immunohistochemistry using chicken plasma, adipose or testis (Ocon-Grove et al. 2008, 
Hendricks et al. 2009). After rinsing in TBS, 1:400 biotinylated goat anti-rabbit IgG (Vector Laboratories, Burlingame, CA, USA) was applied, followed by incubation with 1:100 streptavidin-Alexa 488 (Invitrogen). Tissue sections were then mounted with 1:500 ProLong Gold antifade reagent containing TOPRO-3 (Invitrogen). As a negative control, adiponectin-, ADIPOR1-, or ADIPOR2- antibodies were preadsorbed with respective peptides used for generating the antibodies and used in place of respective primary antibody. Green (adiponectin, ADIPOR1, or ADIPOR2) fluorescent-cells and their nuclei (red) were visualized in Olympus Fluoview 300 Confocal Laser Scanning Microscope (Olympus).

\section{Secretion of adiponectin by theca cells}

Theca layer obtained from broiler breeder hen $(n=6)$ and leghorn hen $(n=6)$ prehierarchical and preovulatory follicles were treated with $0.5 \%$ type II collagenase (Worthington, Waltham, MA, USA) in M199 medium containing $0.2 \%$ BSA in a spinner flask (Bellco, Vineland, NJ, USA) for approximately 45-60 min. The cell suspension was strained through a nylon sieve to remove undigested tissue pieces. The proportion of live and dead cells was determined by trypan blue exclusion test. Approximately, $5 \times 10^{5}$ cells were cultured in tissue culture plates in M199 medium supplemented with $0.2 \%$ D-glucose, $0.2 \% \mathrm{BSA}$, and $1 \times$ antibiotic-antimycotic solution at $40^{\circ} \mathrm{C}$ (chicken body temperature) under $5 \% \mathrm{CO}_{2}$ for $24 \mathrm{~h}$. The culture medium was recovered and stored at $-20^{\circ} \mathrm{C}$. Cells were harvested in lysis buffer (Santa Cruz Biotechnology) containing phosphatase inhibitor cocktail and protease inhibitor (Millipore Sigma) and lysates prepared. The protein content in cell lysates and conditioned culture medium was determined by a protein dye-binding assay (Bradford 1976). Protein extracts were analyzed for the presence of adiponectin multimers by non-reducing and non-heat denaturing native Western blotting using NativePAGE Novex mini gel system (Invitrogen) as described by us previously (Hendricks et al. 2009). The proteins from the gel were electro-transferred to PVDF membrane and immunostained by incubating in 1:40,000 rabbit anti-chicken adiponectin antibody followed by treatment with $0.08 \mu \mathrm{g} / \mathrm{mL}$ horseradish peroxidase (HRP)conjugated goat anti-rabbit IgG (Pierce). Blots were stained with ECLPlus reagent (GE Healthcare), and chemiluminescent signals were detected using the Storm 860 optical scanner (GE Healthcare). Each Western blotting experiment was repeated at least three times to serve as internal replication.

To quantify adiponectin abundance in theca layer cells under basal and stimulated conditions, theca cell cultures were treated with vehicle (negative control), $3 \mu \mathrm{M}$ pioglitazone (PIO; Millipore Sigma) or $25 \mu \mathrm{M}$ eicosapentaenoic acid (EPA; Millipore Sigma). Cultures were incubated for $48 \mathrm{~h}$ at $40^{\circ} \mathrm{C}$ under $5 \% \mathrm{CO}_{2}$. The concentration of EPA and PIO for induction of adiponectin secretion were chosen based on previous reports (Itoh et al. 2007, Banga et al. 2009). Theca layer cell lysates were prepared at the end of the treatment, and protein concentration determined as described above. Western blotting analyses were conducted under reducing conditions, as described previously (Hendricks et al. 2009). Briefly, aliquots of protein extracts $(25 \mu \mathrm{g})$ were heated to $100^{\circ} \mathrm{C}$ for
$10 \mathrm{~min}$ in the presence of reducing agent and separated using $10 \%$ NuPAGE Novex mini gels (Invitrogen). Following transfer of proteins to PVDF membrane, adiponectin was detected by chemiluminescence as described above. The membranes were re-probed using mouse anti- $\alpha$-tubulin antibody $(0.7 \mu \mathrm{g} /$ $\mathrm{mL}$; Millipore Sigma) to determine the abundance of $\alpha$-tubulin quantity. Monomeric adiponectin quantity was expressed as a proportion of $\alpha$-tubulin abundance and subjected to statistical analysis. Cell culture experiments were repeated four times $(n=4)$ while Western blotting experiments were repeated at three times to serve as internal replication.

\section{Multimeric composition of recombinant chicken adiponectin}

Recombinant chicken adiponectin was produced in Chinese hamster ovary (CHO) cell line and in BL21 (De3) Escherichia coli cells, as described in the Supplemental Methods section. To investigate the multimer composition of the recombinant adiponectin prepared in $\mathrm{CHO}$ cells and in E. coli, Western blot analyses were done by separating adiponectin under non-reducing and non-heat denaturing native conditions as well as under denaturing conditions as described previously (Hendricks et al. 2009). The Western blotting experiments were repeated at least three times.

\section{Effect of recombinant chicken adiponectin and adipoRon on pERK and pACC abundance}

Two 9-12 mm follicles and several 6-8 follicles were pooled from two broiler breeder hens to yield an adequate number of granulosa cells for experimentation ( $n=4$ replicates of two broiler breeder hen each). Granulosa layer was separated, and cells dispersed by trituration every $30 \mathrm{~s}$ for up to $3 \mathrm{~min}$. Cells were resuspended in DMEM containing 2-2.5\% FBS and non-essential amino acid solution (GM). The number of viable cells was estimated using trypan blue exclusion test. Granulosa cells $\left(1-5 \times 10^{5}\right.$ cells per tube) were treated with 0 , 25 , or $50 \mu \mathrm{g} / \mathrm{mL}$ recombinant chicken adiponectin expressed in $\mathrm{CHO}$ cells ( $\mathrm{rcADN}$ ), or 0,25 , or $50 \mu \mathrm{M}$ adipoRon (Adipogen Life Sciences, San Diego, CA, USA) for $15 \mathrm{~min}$ at $40^{\circ} \mathrm{C}$ with gentle shaking. AdipoRon, an adiponectin receptor agonist (Okada-Iwabu et al. 2013), is used as a positive control for rcADN. Granulosa cells were pelleted and frozen in lysis buffer containing protease and phosphatase inhibitor cocktail (Millipore Sigma). Cell lysate was prepared, and protein concentration determined as described above. Cellular protein $(25 \mu \mathrm{g})$ was subjected to electrophoresis in 10\% NuPAGE Novex gels (Invitrogen) under reducing conditions. The proteins were electro-transferred to PVDF membrane and immunostained with $0.1 \mu \mathrm{g} / \mathrm{mL}$ rabbit anti-phospho ERK1/2 (pERK; Cell Signaling Technology), $0.1 \mu \mathrm{g} / \mathrm{mL}$ anti-phospho acetyl Co-A carboxylase (pACC; Cell Signaling Technology), or $1 \mu \mathrm{g} / \mathrm{mL}$ anti- $\alpha$-tubulin (Millipore Sigma). Using chemiluminescent detection and image analysis, relative abundance of $p E R K$ or pACC was expressed as a proportion of $\alpha$-tubulin abundance and compared among treatments within each follicle category. Each Western blotting experiment was repeated at least 3 times to serve as internal replication. 


\section{Effect of adiponectin and adipoRon on granulosa STAR gene expression}

Granulosa cells from F2, F3, F4, 9-12 mm, and 6-8 mm follicles ( $n=6$ broiler breeder hens) were dispersed, as described above. Granulosa cells $\left(1-5 \times 10^{5}\right.$ per well) were cultured in $\mathrm{GM}$ at $40^{\circ} \mathrm{C}$ overnight. Granulosa cells were treated with 0 , $50 \mu \mathrm{g} / \mathrm{mL}$ rcADN, or $50 \mu \mathrm{M}$ adipoRon for $24 \mathrm{~h}$ at $40^{\circ} \mathrm{C}$ under $5 \% \mathrm{CO}_{2}$. The supernatant was removed, and the cells were rapidly frozen by placing the dish over a block of dry ice. Total RNA was extracted with RNeasy mini kit (Qiagen) and reverse transcribed as described above. A qPCR was performed, in triplicate, to quantify STAR mRNA or $\beta$-actin mRNA gene expression using $50 \mathrm{ng} \mathrm{CDNA}, 300 \mathrm{nM}$ forward and reverse primers (Supplementary Table 1) and $1 \times$ PerfeCTa SYBR Green Fastmix (Quanta Bio, Beverly, MA, USA) as described above. STAR mRNA quantity was expressed as a proportion of $\beta$-actin mRNA quantity following $2^{-\Delta \Delta \mathrm{Ct}}$ method (Livak \& Schmittgen 2001) and analyzed.

\section{Statistical analysis}

Relative abundance of adiponectin-, ADIPOR1-, ADIPOR2mRNA in granulosa and theca layers at various stages of follicular development and ovarian adiponectin-, ADIPOR1-, ADIPOR2-mRNA abundance in response to $\mathrm{E}_{2}$ and/or $\mathrm{P}_{4}$ administration were determined by ANOVA using the general linear model of the Statistical Analysis System (SAS Institute). The above data set was found to satisfy the assumptions of ANOVA. Differences among individual means were determined by pair-wise comparisons. Relative abundance of adiponectin in theca layer cell lysate in response to EPA or PIO treatment were analyzed by Student's $t$-test. The effect of rcADN or adipoRon on granulosa cell pERK-, pACC-, and $S T A R-$ mRNA abundance within each follicle category were analyzed by Student's $t$-test. A probability level of $P<0.05$ was considered statistically significant.

\section{Results}

\section{Adiponectin-, ADIPOR1- and ADIPOR2-gene expression in ovarian follicles}

Adiponectin cDNA was amplified from ovarian stroma-, granulosa-, and theca-total RNA (Fig. 1). Granulosa cells separated from F1, F3, 9-12 mm, and 6-8 mm follicles did not express adiponectin cDNA but found to express both ADIPOR 1 and ADIPOR2. Adiponectin, ADIPOR1, and ADIPOR2 CDNA were found to be expressed in ovarian stroma and in theca layer of all the above follicle categories.

\section{Relative abundance of adiponectin-, ADIPOR1-, and ADIPOR2-mRNA in preovulatory and prehierarchical follicles}

Adiponectin mRNA abundance did not differ among theca layer isolated from F1, F3, 9-12 mm, and 6-8 $\mathrm{mm}$ follicles (Fig. 2A). ADIPOR1 mRNA abundance in theca layer was significantly higher in $6-8 \mathrm{~mm}$ follicles compared to any other follicles studied (Fig. 2B). ADIPOR2 mRNA abundance did not differ among theca cells isolated from F1, F3, and 9-12 mm follicles. However, ADIPOR2 mRNA abundance was greater in theca cells of $6-8 \mathrm{~mm}$ follicles compared to $\mathrm{F} 3$ follicle (Fig. 2C). ADIPOR 1- and ADIPOR2 mRNA abundance in granulosa cells were significantly greater in the F1 follicle compared to any other follicles studied (Fig. 3A and B). Melting curve analyses showed the presence of a single PCR product for adiponectin-, ADIPOR 1-, ADIPOR2 mRNA, or $\beta$-actin mRNA, confirming the specificity of the reactions (data not shown).

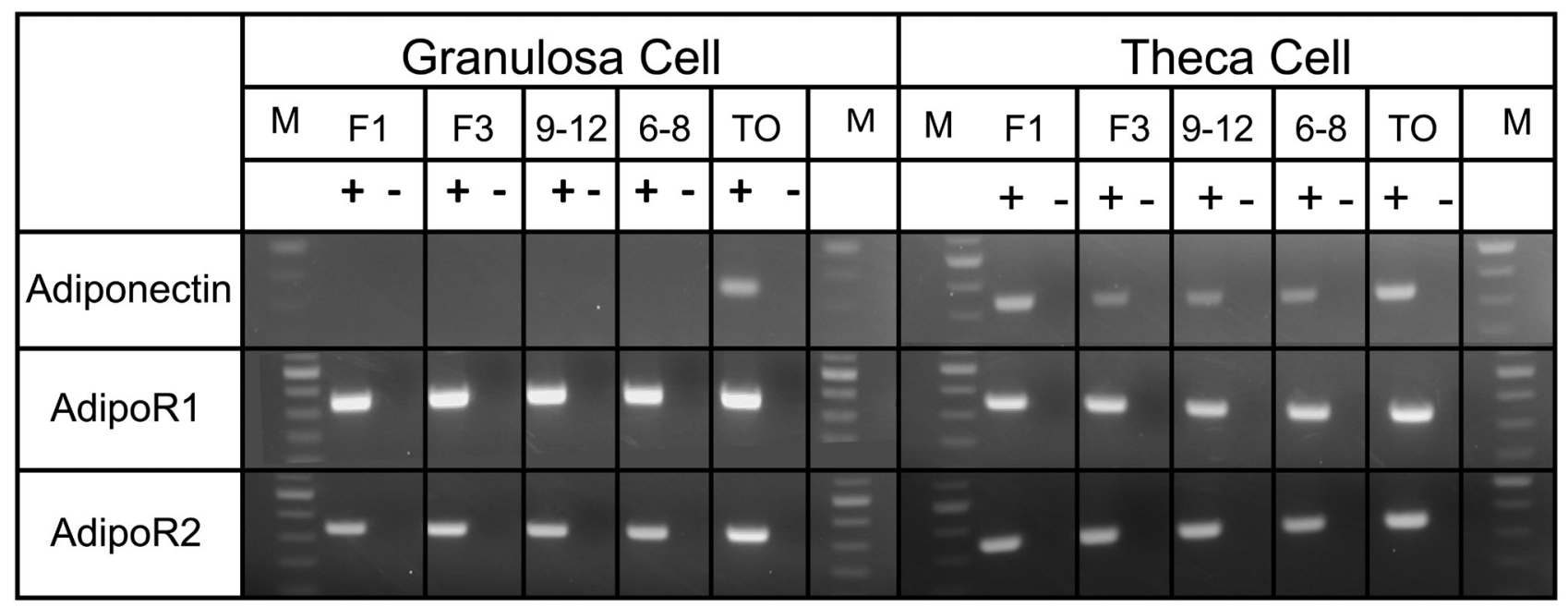

Figure 1 RT-PCR analysis of adiponectin, ADIPOR1, and ADIPOR2 gene expression the chicken ovary. Approximately 100 ng of cDNA (+) prepared from ovarian stroma (TO), granulosa cells and theca cells were used as template to amplify 350-, 350-, and 345-bp chicken adiponectin, ADIPOR, and ADIPOR2 CDNAs, respectively. Negative controls consisted of reverse transcription reactions using follicular RNA without reverse transcriptase (-) or substitution of water for the cDNA template (data not shown). M-DNA standard. 

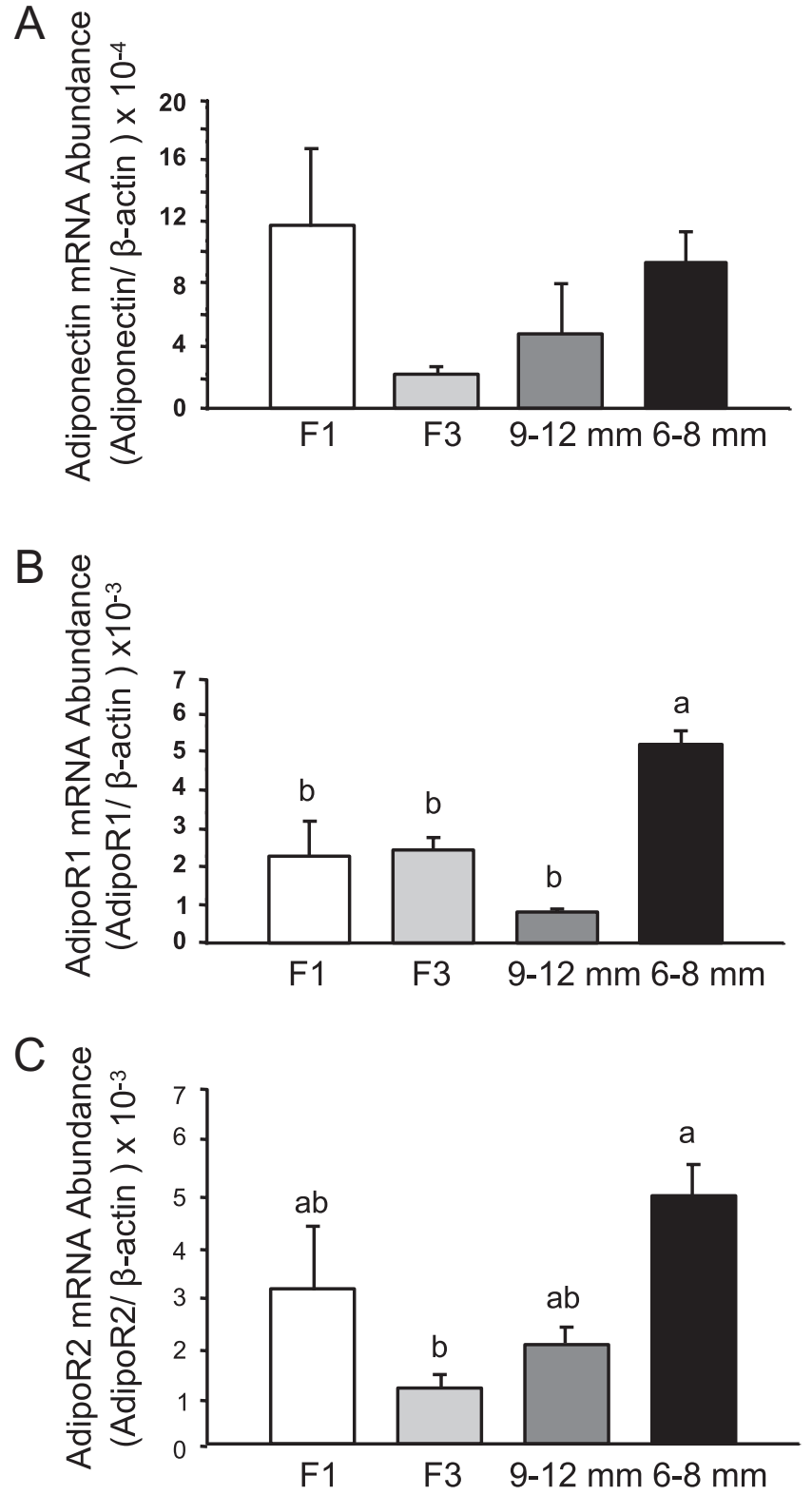

Figure 2 Adiponectin-(A), ADIPOR1-(B), and ADIPOR2- (C) mRNA abundance in theca cells. Total RNA was extracted from theca cell layers of preovulatory follicles (F1, F3, and 9-12 mm), and prehierarchical follicles $(6-8 \mathrm{~mm})$ was treated with deoxyribonuclease-I. Following reverse transcription, approximately $100 \mathrm{ng}$ of cDNA was used in quantitative PCR to quantify adiponectin mRNA, ADIPOR1 mRNA, ADIPOR2 mRNA, or $\beta$-actin mRNA in separate reactions. Each reaction was run in duplicate, and the critical threshold $\left(C_{\mathrm{T}}\right)$ values were averaged, subtracted from that of $\beta$-actin mRNA, and converted from log-linear to linear term. Different letters above each bar indicate significant differences at $P<0.05$. Data represent mean \pm S.E.M. ( $n=6$ leghorn hens).

\section{Effect of $E_{2}$ and/or $P_{4}$ treatment on ovarian adiponectin-, ADIPOR1-, and ADIPOR2-expression}

$E_{2}$ or a combination of $E_{2}$ and $P_{4}$ treatments resulted in a greater abundance of adiponectin mRNA in the ovary when compared to vehicle or $\mathrm{P}_{4}$ tre
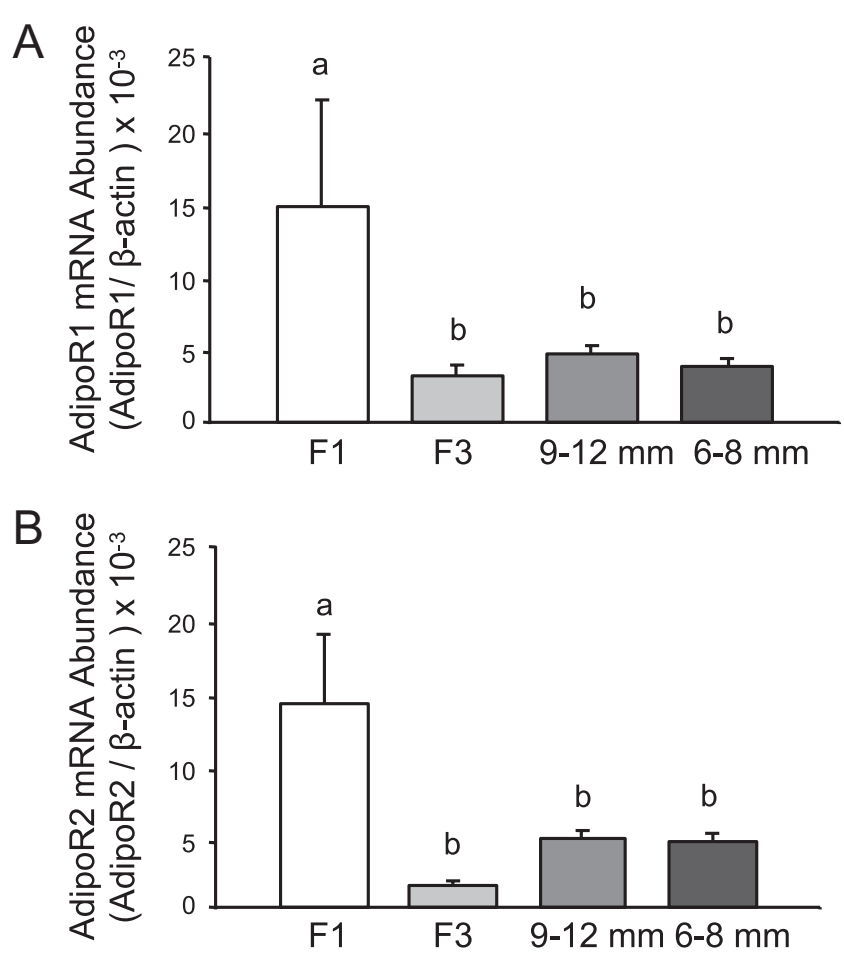

Figure 3 ADIPOR1- (A), and ADIPOR2- (B) mRNA abundance in granulosa cells. Total RNA was extracted from granulosa cells of preovulatory follicles (F1, F3, and 9-12 mm) and prehierarchical follicles $(6-8 \mathrm{~mm})$ and subjected to quantitative real-time PCR as described in the legend to Fig. 2. Different letters above each bar indicate significant difference at $P<0.05$. Data represents mean \pm S.E.M. $(n=6$ leghorn hens).

atments (Fig. 4A). Animals treated with $\mathrm{P}_{4}$ alone had significantly lesser abundance of adiponectin mRNA compared to any other treatment (Fig. 4A). Ovarian ADIPOR1 mRNA abundance was greater in response to $\mathrm{E}_{2}$ treatment compared to any other treatment (Fig. 4B). ADIPOR2 mRNA abundance in the ovary did not differ among all the treatments (Fig. 4C). The oviduct weight was significantly higher in $\mathrm{E}_{2}$ - and/or $\mathrm{P}_{4}$-treated chickens compared to vehicle-treated chickens, confirming the efficacy of the steroid treatments (data not shown).

\section{Immunohistochemical localization of adiponectin, ADIPOR1, and ADIPOR2 in ovarian follicles}

Representative localization of adiponectin-, ADIPOR1-, and ADIPOR2-immunoreactive (ir) cells within a primary follicle is shown in Fig. 5A, B, C, D, E, F, G, H and I. Adiponectin-ir cells were observed in the theca layer but were undetectable in the granulosa cell layer (Fig. 5A, $\mathrm{B}$ and $\mathrm{C})$. ADIPOR1- and ADIPOR2-immunostaining observed in both theca and granulosa cell layers (Fig. 5D, E, F, G, H and I) appeared punctate, a pattern typical of transmembrane receptors. When adiponectin-, ADIPOR1-, or ADIPOR2- antibodies preadsorbed with respective peptides used for generating the antibodies 

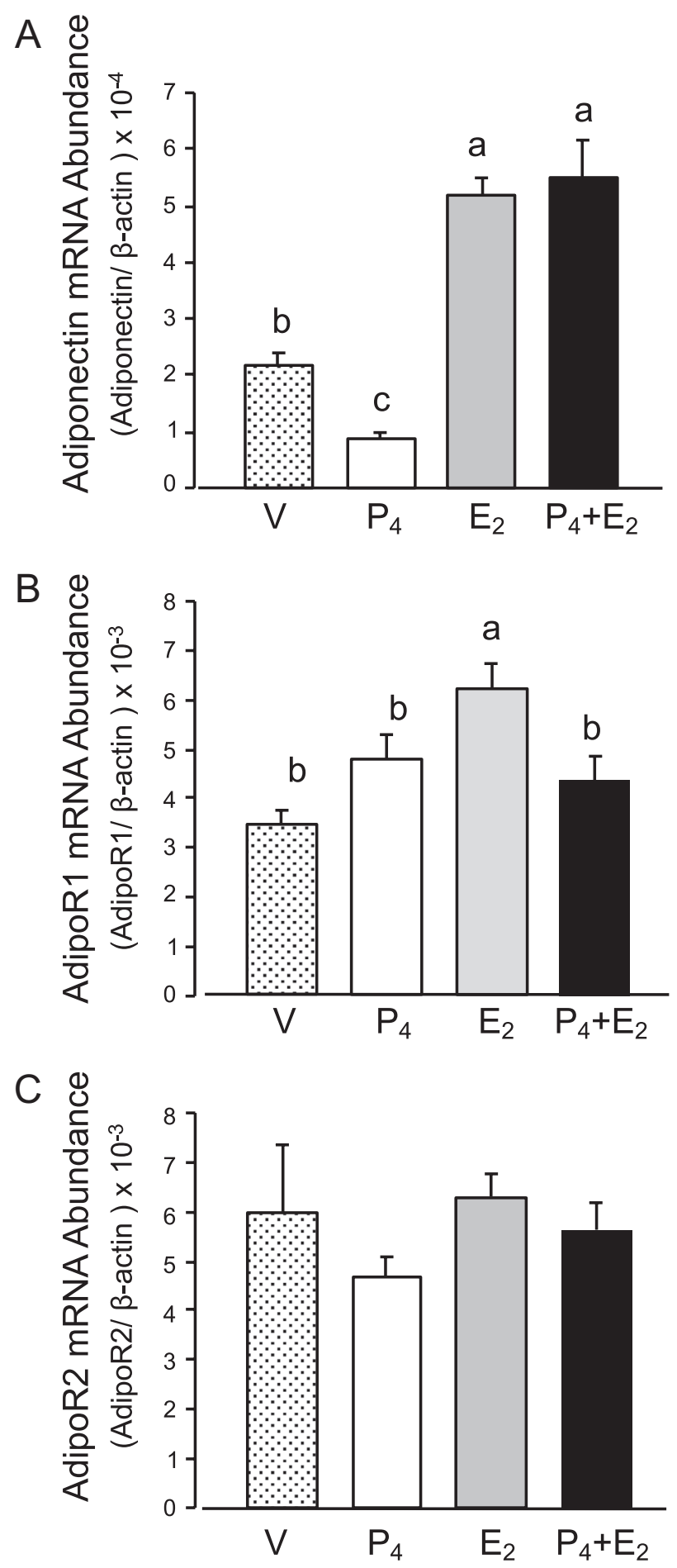

Figure 4 Effect of estradiol $\left(\mathrm{E}_{2}\right)$ and/or progesterone $\left(\mathrm{P}_{4}\right)$ on adiponectin, ADIPOR1, or ADIPOR2 mRNA abundance in the chicken ovary. Sexually immature female chickens were treated with $\mathrm{E}_{2}, \mathrm{P}_{4}, \mathrm{E}_{2}+\mathrm{P}_{4}$, or vehicle ( $n=7$ leghorn chickens per treatment). Chickens were euthanized at the end of treatments to collect ovarian stroma. Total RNA extracted from the ovary was subjected to real-time quantitative PCR to determine adiponectin, ADIPOR1, or ADIPOR2 mRNA quantity as described in the Fig. 2 legend. Data (mean \pm S.E.M.) with different letters above each bar represents significant difference at $P<0.05$. were used in place of respective primary antibody, immunostaining was abolished (Fig. 5L).

\section{Adiponectin secretion from theca layer cells}

Western blot analysis under non-reducing and non-heatdenaturing conditions revealed a strong immunoreactive band with a molecular mass of approximately 720 $\mathrm{kDa}$ in broiler chicken plasma (included as a positive control), theca layer cellular lysate, and in the theca layer cell-conditioned medium (Fig. 6A; arrows). Adiponectin secreted from the theca layer cells appears to have another isoform that is slightly $>720 \mathrm{kDa}$ that may represent an isoform unique to thecal cell secretion. Although this analysis is not quantitative, the abundance of adiponectin in theca layer cells appeared much lesser than in chicken plasma. Treatment of theca layer cells cultured in vitro with PIO or EPA, at dosages that are known to augment adiponectin secretion from adipocytes, significantly increased the abundance of the $30 \mathrm{kDa}$ adiponectin monomer (Fig. 6B).

\section{Production of recombinant chicken adiponectin}

Full-length recombinant chicken adiponectin was purified from eukaryotic and prokaryotic cell cultures. Immunoblotting under non-reducing and non-heatdenaturing conditions (Fig. 7A) revealed that rcADN expressed in CHO-cells (E; Fig. 7A and B) consists of two isoforms of $720 \mathrm{kDa}$ and $242 \mathrm{kDa}$ mass (arrows in Fig. 7A), whereas the recombinant adiponectin expressed in E. coli (rbADN; $\mathrm{P}$ in Fig. 7A and $\mathrm{B}$ ) is a mixture of several isoforms ranging in mass from 720 to $146 \mathrm{kDa}$. Under reducing electrophoretic conditions (Fig. 7B), omission of heat and reducing agent to rcADN resulted in a major immunoreactive band that is $>191$ $\mathrm{kDa}$ in size as well as a few isoforms around $64 \mathrm{kDa}$. However, under the same electrophoretic conditions, rbADN appears predominantly as a $30 \mathrm{kDa}$ monomer form along with other oligomers (arrow; Fig. 7B). The addition of reducing agent and heating to $70-100^{\circ} \mathrm{C}$, however, lead to a progressive reduction in multimers with a concomitant increase in the $30 \mathrm{kDa}$ monomer in rcADN, rbADN, and in chicken plasma (arrows in Fig. 7B). Recombinant chicken adiponectin was found to be biologically active (Supplementary methods and Supplementary Fig. 3) as determined by an increase in the abundance of pAMPK, pACC, pERK, and pAkt in chicken hepatocellular carcinoma (LMH) cell line.

\section{Effect of rcADN and adipoRon on granulosa cell pERK, pACC, and STAR mRNA abundance}

Phospho-ERK, but not pACC abundance was significantly greater in granulosa cells of $6-8 \mathrm{~mm}$ follicles treated with rcADN or adipoRon (Fig. 8). The granulosa cells dispersed from 9 to $12 \mathrm{~mm}$ follicles had 


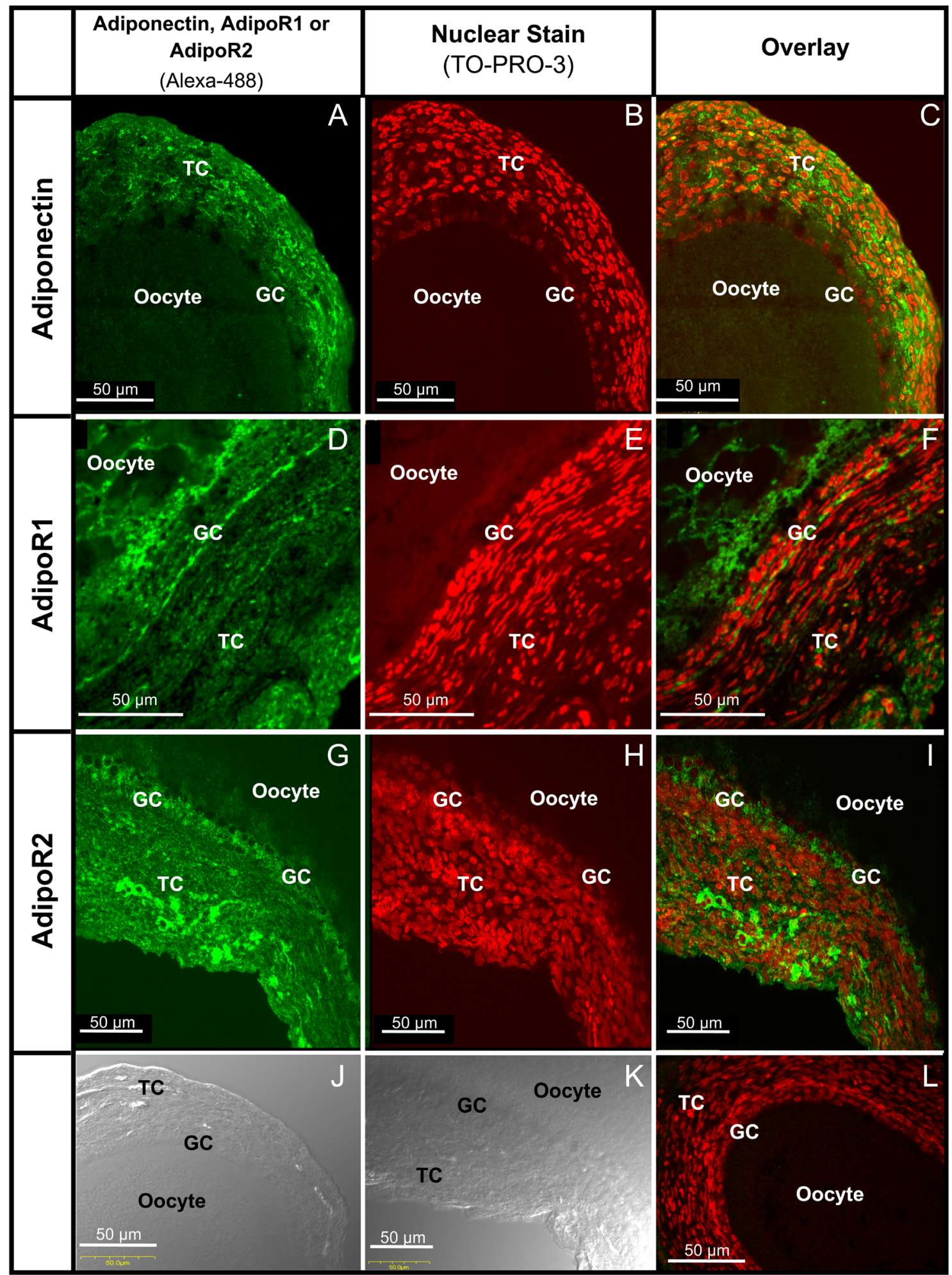

Figure 5 Representative confocal images of ovarian follicle from sexually mature chicken showing adiponectin-, ADIPOR1- and ADIPOR2immunostained cells. Paraformaldehyde-fixed tissue sections were immunostained using anti-chicken adiponectin (A, B and C), anti-chicken ADIPOR1 (D, E and F), anti-chicken ADIPOR2 (G, H and I) antibodies as described in Materials and Methods section. Adiponectin immunostaining (green; A and C) was noticed only within the theca layer (TC) but not in the granulosa cell (GC) layer. ADIPOR1 immunostaining (green; D and F) and ADIPOR2 immunostaining (green; G and I) were present in both the TC and GC. (J and K) Phase contrast images of the ovarian follicles shown in A and G, respectively. Representative photomicrographs of ovarian tissue sections immunostained with primary antibodies that were preadsorbed with respective antigens as negative control and counterstained to reveal nuclei (red; L). 


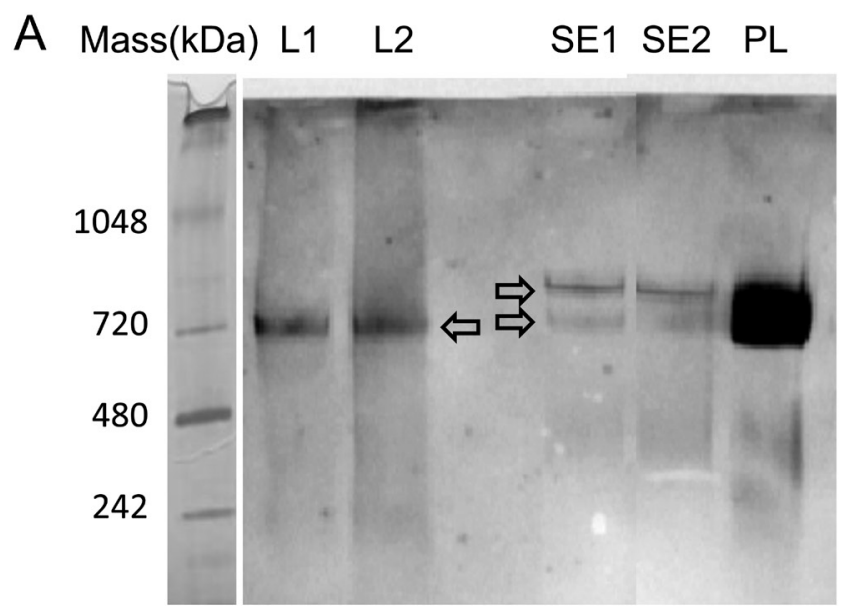

B

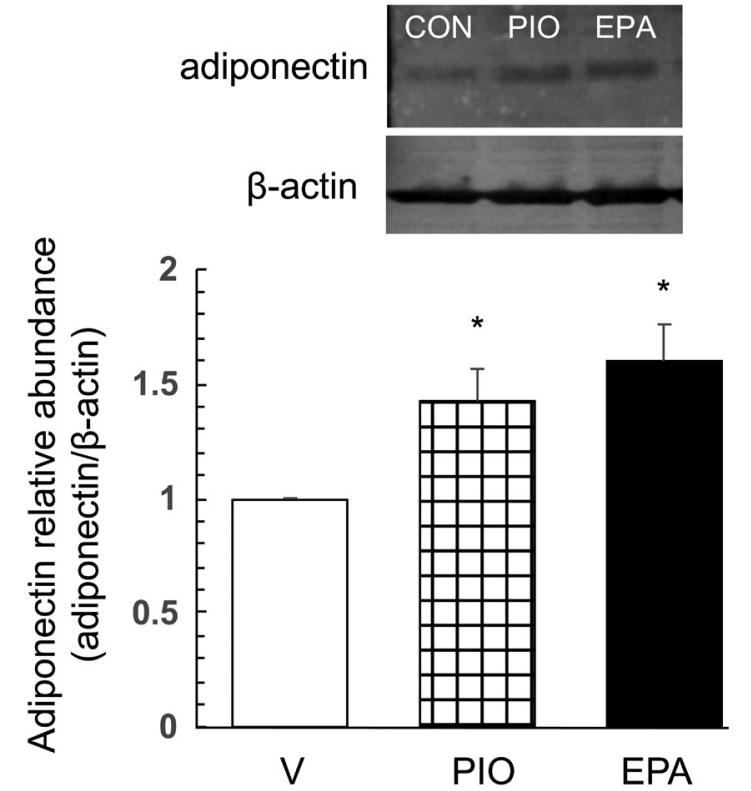

Figure 6 (A) Non-reducing and non-heat-denaturing Western blot analysis of adiponectin expressed by theca cells under native conditions. Theca cell protein lysates (L1 and L2) and serum-free theca-conditioned media (SE1 and SE2) were separated by electrophoresis under native (non-reducing and non-heat-denaturing) conditions (see Materials and methods). Adiponectin was detected using anti-chicken adiponectin antibody. Chicken plasma (PL; $0.5 \mu \mathrm{l}$ ), separated under the same native conditions, was used as positive control. A protein molecular weight standard was included in the electrophoresis to identify the mass of adiponectin. Arrows indicate heavy molecular weight isoforms of adiponectin. ( $n=6$ broiler breeder and leghorn hens each). (B) Effect of pioglitazone (PIO) and eicosapentaenoic acid (EPA) on adiponectin abundance in theca cell lysates. Theca cells were treated with vehicle (V), $3 \mu \mathrm{M}$ PIO, or 25 $\mu \mathrm{M} \mathrm{EPA}$, for $48 \mathrm{~h}$ and a lysate was prepared. The lysates were denatured and heated to $100^{\circ} \mathrm{C}$ before subjected to electrophoresis under reducing conditions and transferred to PVDF membrane. Adiponectin and $\beta$-actin were detected by immunostaining using a rabbit anti-chicken adiponectin antibody and a mouse anti- $\beta$-actin antibody, respectively. The abundance of adiponectin relative to $\beta$-actin abundance was calculated by image analysis. ${ }^{*} P<0.05$ compared to vehicle control; $n=4$ chickens.

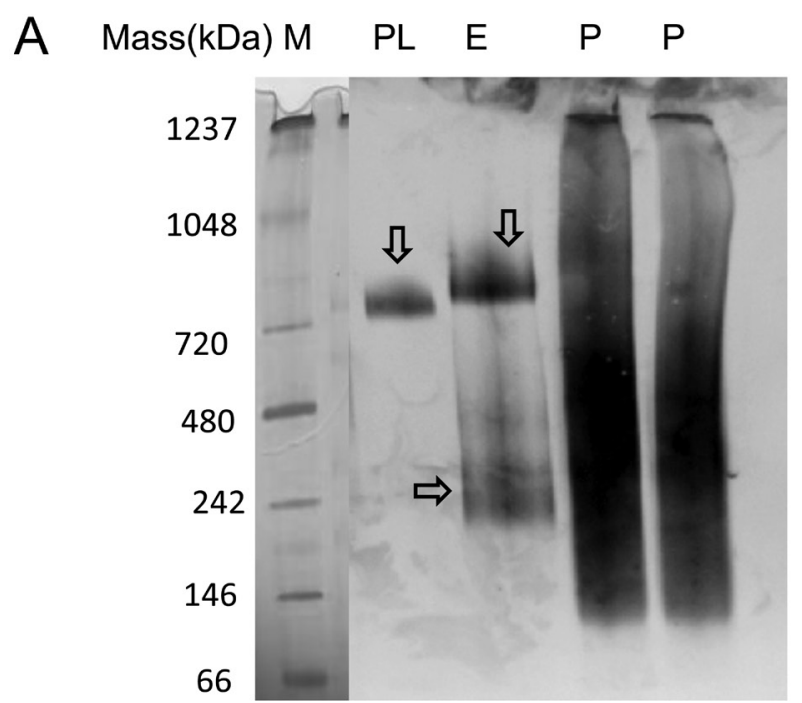

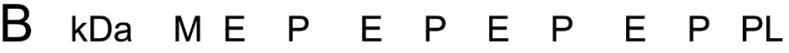

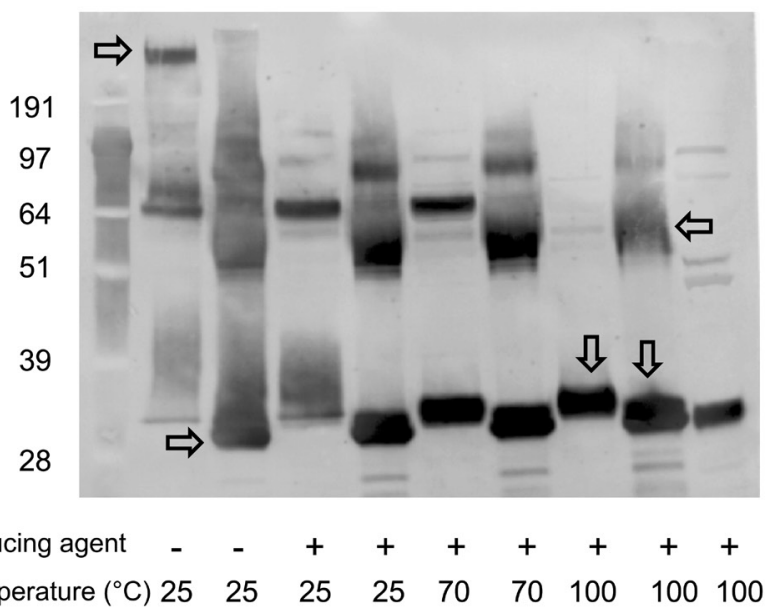

Figure 7 Isoforms of recombinant adiponectin expressed in eukaryotic cells and in prokaryotic cells. Full-length cDNA encoding chicken adiponectin was transfected into eukaryotic cells (CHO-K1 cells) and prokaryotic cells (E. coli). Recombinant adiponectin secreted from eukaryotic cells ( $r$ ADN; denoted $\mathrm{E}$ ) and in prokaryotic cells (rbADN; denoted $\mathrm{P}$ ) were purified and subjected to nonreducing non-heat denaturing gel electrophoresis $(\mathrm{A})$ and to denaturing electrophoresis with or without reducing agent and temperature ranging from 25 to $100^{\circ} \mathrm{C}$ (B). Chicken plasma (PL; 0.5 $\mu \mathrm{L}$ ) was included as positive control for adiponectin as plasma adiponectin levels in chickens are at least $4 \mu \mathrm{g} / \mathrm{ml}$ (Hendricks et al. 2009). Arrows in A and B indicate isoforms of recombinant adiponectin discussed in the Results section.

a greater abundance of pERK when treated with 25, $50 \mu \mathrm{g} / \mathrm{mL} \mathrm{rcADN}$, or $25 \mu \mathrm{M}$ adipoRon compared to vehicle treatment (Fig. 8). Similarly, pACC abundance was greater in response to $25,50 \mu \mathrm{g}$ rCADN, or $50 \mu \mathrm{M}$ adipoRon treatment compared to vehicle treatment of 9-12 mm follicle granulosa cells (Fig. 8). Treatment of granulosa cells dispersed from 6-8 mm, 9-12 mm, F4, 


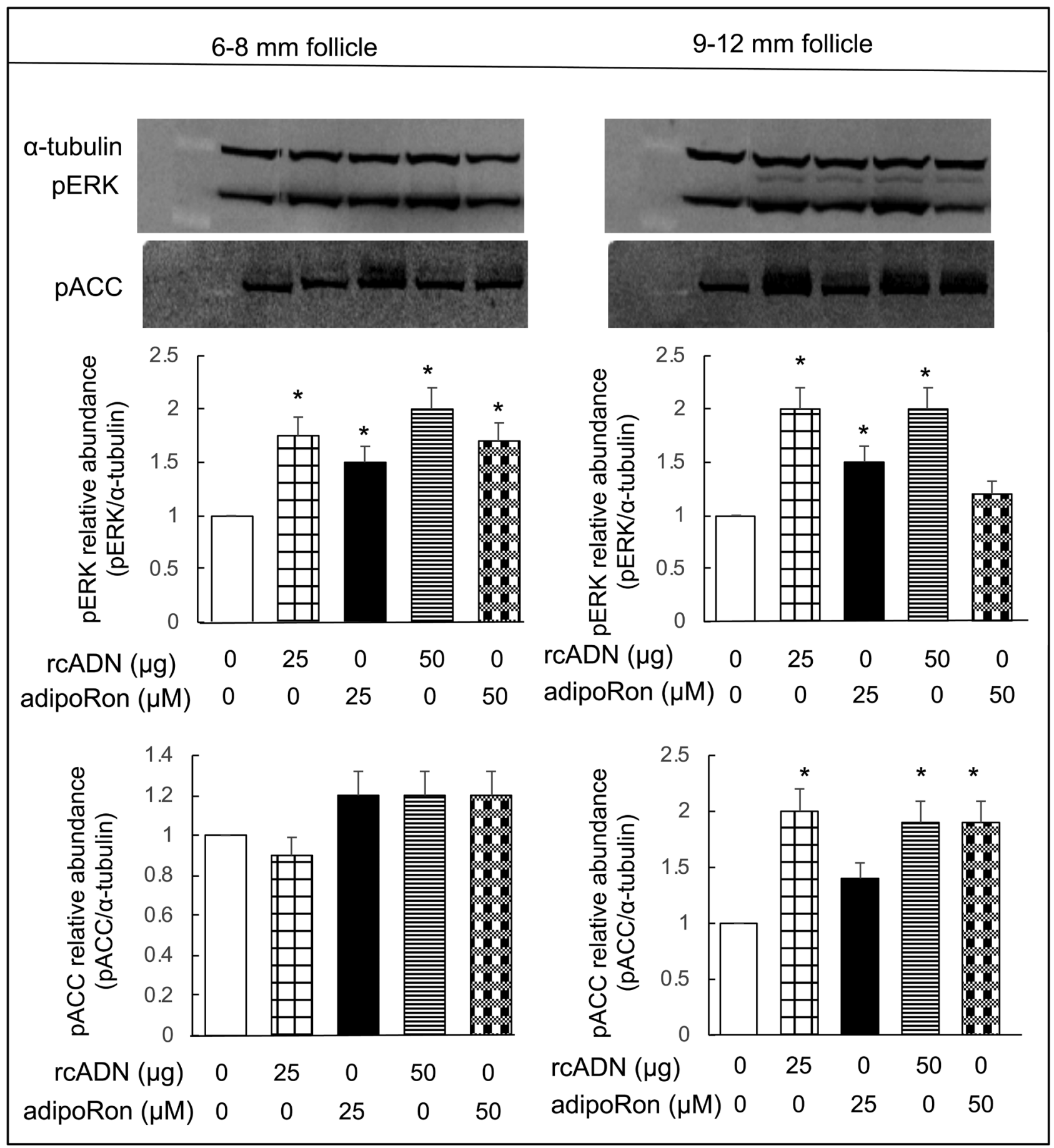

Figure 8 Effect of recombinant adiponectin or adipoRon on pERK1/2 and pACC abundance in granulosa cells. Granulosa cells from prehierarchical follicles $(6-8 \mathrm{~mm})$ and preovulatory follicles $(9-12 \mathrm{~mm})$ were dispersed to single-cell suspensions and treated with rcADN $(0$, $25,50 \mu \mathrm{g} / \mathrm{mL})$ or adipoRon $(0,25$ or $50 \mu \mathrm{M})$ for $15 \mathrm{~min}$ at $40^{\circ} \mathrm{C}$. Cell lysates were prepared following treatment, and a Western blot analysis was performed under reducing conditions to quantify the abundance of pERK1/2, pACC, and $\alpha$-tubulin, as described in the Materials and methods section. The relative abundance of pERK1/2 or pACC was determined as a proportion of $\alpha$-tubulin abundance. ${ }^{*} P<0.05$ compared to vehicle control; $n=4$ replicates of two broiler breeder hens each. 


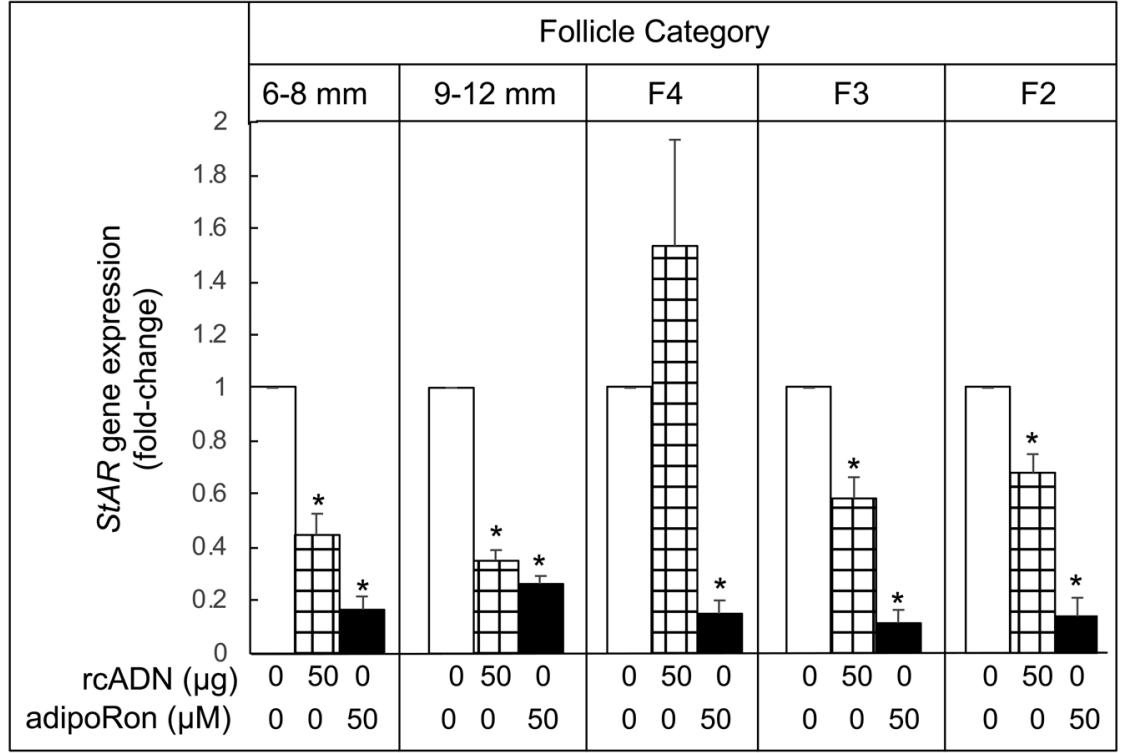

Figure 9 Effect of recombinant adiponectin or adipoRon on STAR gene expression in granulosa cells. Granulosa cells were dispersed from prehierarchical follicles (6-8 $\mathrm{mm}$ ) and preovulatory follicles (9-12 mm, F4, F3, and F2) and treated with either 0,50 $\mu \mathrm{g} /$ $\mathrm{mL}$ rcADN or $50 \mu \mathrm{M}$ adipoRon. Total RNA was extracted and reverse transcribed to quantify STAR mRNA or $\beta$-actin mRNA by quantitative PCR, as described in the Materials and methods section. ${ }^{*} P<0.05$ compared to vehicle control within each follicle category; $n=6$ broiler breeder hens.
F3, and F2 follicles with rcADN or adipoRon resulted in a significantly lesser STAR mRNA abundance compared to vehicle control in all the follicle categories except F4 follicle (Fig. 9).

\section{Discussion}

We report for the first time, in any species, that adiponectin is synthesized and secreted from ovarian follicular cells. The expression of adiponectin-, ADIPOR1-, and ADIPOR2-mRNA in the chicken ovary has been described previously (Chabrolle et al. 2007a). We found that the adiponectin gene is expressed in the theca layer, but not in the granulosa cells of all follicle categories studied, consistent with a previous study (Chabrolle et al. 2007a) that found that adiponectin mRNA was 30 -fold greater in theca cells compared to granulosa cells of preovulatory follicles. Although we did not find any difference in the abundance of adiponectin mRNA in any of the follicle studied, a previous study (Chabrolle et al. 2007a) found greater adiponectin mRNA in F1 compared to F3 or F4 follicles, possibly due to differences in the animal strain used in the studies. As in chickens, turkey ovarian theca cells were found to express greater adiponectin mRNA compared to granulosa cells of the preovulatory follicles (Diot et al. 2015). The expression of adiponectin, ADIPOR1, and $A D I P O R 2$ in mammalian ovaries has been extensively documented (Maillard et al. 2010, Singh \& Krishna 2012b, Comim et al. 2013, Maleszka et al. 2014). Taken together, expression of adiponectin and its receptor in the ovary is conserved among mammalian and avian species, and therefore may have important biological functions in the ovary.

This the first report documenting the localization of cells expressing adiponectin, ADIPOR1, and ADIPOR2 in chicken ovarian follicles. Consistent with our RT-PCR data, we found adiponectin-ir cells in the theca layer but not in the granulosa layer while both ADIPOR1- and ADIPOR2-ir cells were found both in granulosa and theca layers. Adiponectin-, ADIPOR1-, or ADIPOR2immunostaining were found in theca cells, interstitial cells, corpus luteum, and in granulosa cells of the rat ovary (Chabrolle et al. 2007b). Adiponectin-immunostaining was observed primarily in theca and interstitial cells, whereas ADIPOR1 was found to be present in granulosa cells of bat ovary (Singh \& Krishna 2012b). Adiponectinimmunostaining was detected in granulosa and theca cells, whereas ADIPOR1 and ADIPOR2 was localized in oocytes, cumulus cells, granulosa and theca cells of goat ovary (Oliveira et al. 2017). Tissue sections of human polycystic ovaries were found to contain fewer ADIPOR1- and ADIPOR2-ir theca cells compared to normal ovaries (Comim et al. 2013). The presence of adiponectin in the ovarian follicular cells suggests that adiponectin is synthesized locally in the ovary and likely to activate adiponectin receptors.

We investigated the effects of $\mathrm{E}_{2}$ and/or $\mathrm{P}_{4}$, the two major ovarian steroids, on adiponectin, $A D I P O R 1$, and $A D I P O R 2$ expression in the ovary of sexually immature pullets wherein follicular development has not matured and therefore do not contain prehierarchical and preovulatory follicles, the two predominant sources of $\mathrm{E}_{2}$ and $\mathrm{P}_{4}$. Our data suggest that $\mathrm{E}_{2}$ - and/or $\mathrm{P}_{4}$-treatment alters the abundance of ovarian adiponectin and ADIPOR1-mRNA, but not ADIPOR2 mRNA, suggesting potential regulation by $\mathrm{E}_{2}$ and/or $\mathrm{P}_{4}$. Administration of $\mathrm{E}_{2}$ alone or in combination with $\mathrm{P}_{4}$ significantly increased the abundance of ovarian adiponectin mRNA while $\mathrm{P}_{4}$ administration alone significantly decreased adiponectin mRNA abundance. We have earlier found that ovarian adiponectin gene expression was significantly greater in mutant restricted ovulator (RO) chickens (data not shown). The $\mathrm{RO}$ chickens have a single nucleotide mutation in 
the VLDL receptor gene resulting in defective oocyte uptake of lipoproteins (Bujo et al. 1995), greater plasma estrogen, and lower plasma progesterone concentration (Leszczynski et al. 1984, Ocon-Grove et al. 2007). An increase in $A D I P O R 1$ expression by $E_{2}$ was found to be blunted by concomitant $\mathrm{P}_{4}$ administration, suggesting that $E_{2}$ and $P_{4}$ may counteract each other in affecting the expression of ADIPOR1. Administration of human chorionic gonadotropin and pregnant mare gonadotropin to sexually immature rats increased the abundance of adiponectin and ADIPOR 1 in the ovary, whereas the ADIPOR2 levels remained unchanged (Chabrolle et al. 2007b). Sexual maturation in chickens was found to be associated with an increase in testicular ADIPOR1and ADIPOR2 gene expressions (OconGrove et al. 2008). Based on the foregoing, gonadal steroids and gonadotropins are likely to regulate the expression of adiponectin and its receptors in the ovary.

This is the first report documenting the synthesis and secretion of adiponectin from ovarian follicular cells. We found that theca layer cells cultured in vitro and theca layer cell-conditioned media contained predominantly an HMW isoform of adiponectin that is consistent with the multimeric nature of adipocyte-derived, and circulating adiponectin in chickens (Hendricks et al. 2009). Adiponectin was detected in human, cow, and pig follicular fluid that may have originated from blood and/ or follicular cells. Analysis of adiponectin isoforms in the follicular fluid of gonadotropin-administered women suggests that follicular fluid adiponectin is composed of $23.3 \%$ of the $\mathrm{HMW}$ isoform compared to $50 \%$ in sera at the time of follicular recruitment (Bersinger \& Wunder 2010). Ovarian follicular fluid from heifers and seminal plasma from breeding bulls contained greater MMW and HMW multimers of adiponectin, respectively, compared to sera (Heinz et al. 2015). Synthesis of adiponectin in theca cells is likely to be controlled by activation of PPAR- $\gamma$ as we found that thecal adiponectin abundance was elevated by treatment with EPA or PIO, the two potent PPAR- $\gamma$ agonists that are proven to increase adiponectin translation in adipose tissue (Itoh et al. 2007, Banga et al. 2009). In summary, theca layer derived-adiponectin is likely to supplement blood-borne adiponectin within the ovary to exert biological effects.

Preliminary studies conducted in our laboratory indicated that mammalian adiponectin was not biologically active in a consistent manner when tested in chicken hepatocyte and granulosa cell cultures. This is most likely due to poor conservation of adiponectin sequence between mammalian and avian species (Maddineni et al. 2005). Therefore, we produced chicken-specific recombinant adiponectin by in prokaryotic and eukaryotic expression systems. Our data suggests that the mobility of eukaryotic-cell derived adiponectin during electrophoresis under native conditions was similar to plasma- and adipose- tissue derived adiponectin (Hendricks et al. 2009). In contrast, bacterially expressed chicken adiponectin multimers appeared to be unstable, resulting in a mixture of several multimeric isoforms. This suggests that recombinant adiponectin expressed in eukaryotic cells, as opposed to bacterially expressed adiponectin, would have undergone appropriate hydroxylation and glycosylation required for multimerization and stability of the HMW multimer (Richards et al. 2006, Wang et al. 2006, Hendricks et al. 2009).

We found that rcADN treatment increased the abundance of pERK and pACC in granulosa cells isolated from 6-8 $\mathrm{mm}$ and 9-12 $\mathrm{mm}$ follicles, the largest prehierarchical follicle and the smallest preovulatory follicle recruited into the hierarchy, respectively. They were chosen to determine the effect of rcADN primarily due to the rapid increase in granulosa cell proliferation and differentiation typically observed around the time of recruitment of a follicle into the preovulatory pool. Activation by phosphorylation of ERK controls several mitogen-induced cellular responses such as proliferation, differentiation, and survival (Roux \& Blenis 2004). Consistent with our results, recombinant porcine adiponectin treatment increases phosphorylation of ERK (Ledoux et al. 2006). ADIPOR2 appears to be mediating the effect of adiponectin in activating ERK signaling pathway based on the report that ADIPOR2-knockdown in human granulosa tumor (KGN) cell line decreased pERK abundance in response to FSH treatment compared to ADIPOR2-intact cells (Pierre et al. 2009). Recombinant human adiponectin increased the abundance of pERK in bovine granulosa cells (Maillard et al. 2010). Adiponectin decreased insulin-induced steroidogenesis but increased insulinlike growth factor-1-induced proliferation of bovine granulosa cells through a potential involvement of the ERK pathway (Maillard et al. 2010).

We found that pACC abundance in granulosa cells of 9-12 mm follicles was increased in responseto adiponectin treatment. Increased abundance of pACC would result in inactivity of ACC enzyme, thereby decreasing cellular malonyl Co-enzyme A content and increasing fatty acid oxidation (Tsao et al. 2002), thus favoring catabolism and decreasing steroidogenesis. Administration of recombinant adiponectin to mice resulted in an increase in hepatic pACC abundance (Yamauchi et al. 2002). We utilized adipoRon as a positive control for rCADN since several reports suggest that this small molecule activates adiponectin receptor (Zhang et al. 2015) both in vitro and in vivo (Zhang et al. 2015, Akimoto et al. 2018, Yamashita et al. 2018, Zheng et al. 2019) when tested in mouse models. We observed that rcADN and adipoRon elicited similar responses in pERK and pACC abundance in granulosa cells. Therefore, adipoRon could potentially be used in avian species as an adiponectin receptor agonist in the future. 
This is the first report describing the effect of adiponectin and adipoRon on STAR gene expression in chicken ovarian follicular cells. We found significantly lesser STAR mRNA abundance when granulosa cells isolated from preovulatory and prehierarchical follicles were treated with rcADN or adipoRon compared to controls. Assuming a potential decrease in STAR protein abundance as a result of adiponectin treatment, cholesterol transport into mitochondria is likely to be diminished, leading to a decrease in steroidogenesis. Interestingly, we found that granulosa isolated from F1 follicle, where maximal $\mathrm{P}_{4}$ synthesis occurs, expressed greater levels of ADIPOR1 and ADIPOR2 gene expression. Adiponectin, therefore, may exert a counter-regulatory influence to regulate $\mathrm{P}_{4}$ secretion. The effect of recombinant adiponectin on ovarian STAR gene expression is not unequivocal. For instance, adiponectin was found to increase STAR mRNA in porcine follicular cells (Ledoux et al. 2006) and in goose granulosa cells (Meng et al. 2019) whereas incubation of cultured bovine theca cells with adiponectin was found to decrease LH-induced STAR gene expression in addition to suppressing steroidogenic enzymes and androstenedione production (Comim et al. 2016). Such divergent responses could potentially be due to variation in the multimeric composition of recombinant adiponectin used in the studies. Furthermore, the overall effect of adiponectin on ovarian steroidogenesis appears to be dependent on the presence or absence of gonadotropins and growth factors (Chabrolle et al. 2007a,b, Pierre et al. 2009, Maillard et al. 2010, Singh \& Krishna 2012a, Maleszka et al. 2014, Comim et al. 2016) in addition to the multimeric status of recombinant adiponectin.

In summary, we provide novel evidence that ovarian follicular theca cells synthesize and secret adiponectin that is similar in multimeric composition to that of adipose-derived adiponectin. Theca-secreted adiponectin may have an autocrine or paracrine effect on theca and granulosa cell steroidogenesis, proliferation, and metabolism. Further studies are required to elucidate the molecular mechanisms that underlie the effect of adiponectin on ovarian follicular maturation and ovulation in chickens.

\section{Supplementary materials}

This is linked to the online version of the paper at https://doi. org/10.1530/REP-19-0505.

\section{Declaration of interest}

The authors declare that there is no conflict of interest that could be perceived as prejudicing the impartiality of the research reported.

\section{Funding}

This project was supported by Agriculture and Food Research Initiative Competitive Grant no. 2017-67015-26506 from the USDA National Institute of Food and Agriculture.

\section{Author contribution statement}

Both Jill Hadley and Olga Ocon-Grove designed and conducted the experiments and analysed data. Jill Hadley and Ramesh Ramachandran wrote the manuscript.

\section{Acknowledgements}

The authors wish to thank Dr Gilbert Hendricks, III for purification and analysis of recombinant chicken adiponectin. This project was supported by Agriculture and Food Research Initiative Competitive Grant no. 2017-67015-26506 from the USDA National Institute of Food and Agriculture.

\section{References}

Akimoto M, Maruyama R, Kawabata Y, Tajima Y \& Takenaga K 2018 Antidiabetic adiponectin receptor agonist AdipoRon suppresses tumour growth of pancreatic cancer by inducing RIPK1/ERK-dependent necroptosis. Cell Death and Disease 9 804. (https://doi.org/10.1038/ s41419-018-0851-z)

Arita Y, Kihara S, Ouchi N, Takahashi M, Maeda K, Miyagawa J, Hotta K, Shimomura I, Nakamura T, Miyaoka K et al. 1999 Paradoxical decrease of an adipose-specific protein, adiponectin, in obesity. Biochemical and Biophysical Research Communications 257 79-83. (https://doi. org/10.1006/bbrc.1999.0255)

Aroda V, Ciaraldi TP, Chang SA, Dahan MH, Chang RJ \& Henry RR 2008 Circulating and cellular adiponectin in polycystic ovary syndrome: relationship to glucose tolerance and insulin action. Fertility and Sterility 89 1200-1208. (https://doi.org/10.1016/j.fertnstert.2007.04.046)

Banga A, Unal R, Tripathi P, Pokrovskaya I, Owens RJ, Kern PA \& Ranganathan G 2009 Adiponectin translation is increased by the PPARgamma agonists pioglitazone and omega-3 fatty acids. American Journal of Physiology: Endocrinology and Metabolism 296 E480-E489. (https://doi.org/10.1152/ajpendo.90892.2008)

Bersinger NA \& Wunder DM 2010 Adiponectin isoform distribution in serum and in follicular fluid of women undergoing treatment by ICSI. Acta Obstetricia et Gynecologica Scandinavica 89 782-788. (https://doi. org/10.3109/00016341003657918)

Bongrani A, Mellouk N, Rame C, Cornuau M, Guerif F, Froment P \& Dupont J 2019 Ovarian expression of adipokines in polycystic ovary syndrome: a role for chemerin, omentin, and apelin in follicular growth arrest and ovulatory dysfunction? International Journal of Molecular Sciences 20 E3778. (https://doi.org/10.3390/ijms20153778)

Bradford MM $1976 \mathrm{~A}$ rapid and sensitive method for the quantitation of microgram quantities of protein utilizing the principle of proteindye binding. Analytical Biochemistry 72 248-254. (https://doi. org/10.1016/0003-2697(76)90527-3)

Bujo H, Yamamoto T, Hayashi K, Hermann M, Nimpf J \& Schneider WJ 1995 Mutant oocytic low density lipoprotein receptor gene family member causes atherosclerosis and female sterility. PNAS 92 9905-9909. (https://doi.org/10.1073/pnas.92.21.9905)

Chabrolle C, Tosca L, Crochet S, Tesseraud S \& Dupont J 2007a Expression of adiponectin and its receptors (AdipoR1 and AdipoR2) in chicken ovary: potential role in ovarian steroidogenesis. Domestic Animal Endocrinology 33 480-487. (https://doi.org/10.1016/j.domaniend.2006.08.002)

Chabrolle C, Tosca L \& Dupont J 2007b Regulation of adiponectin and its receptors in rat ovary by human chorionic gonadotrophin treatment and potential involvement of adiponectin in granulosa cell steroidogenesis. Reproduction 133 719-731. (https://doi.org/10.1530/REP-06-0244) 
Cheng L, Shi H, Jin Y, Li X, Pan J, Lai Y, Lin Y, Jin Y, Roy G, Zhao A et al. 2016 Adiponectin deficiency leads to female subfertility and ovarian dysfunctions in mice. Endocrinology 157 4875-4887. (https://doi. org/10.1210/en.2015-2080)

Comim FV, Hardy K \& Franks S 2013 Adiponectin and its receptors in the ovary: further evidence for a link between obesity and hyperandrogenism in polycystic ovary syndrome. PLOS ONE 8 e80416. (https://doi. org/10.1371/journal.pone.0080416)

Comim FV, Gutierrez K, Bridi A, Bochi G, Chemeris R, Rigo ML, Dau AM, Cezar AS, Moresco RN \& Goncalves PB 2016 Effects of adiponectin including reduction of androstenedione secretion and ovarian oxidative stress parameters in vivo. PLOS ONE 11 e0154453. (https://doi. org/10.1371/journal.pone.0154453)

Diot M, Reverchon M, Rame C, Froment P, Brillard JP, Briere S, Leveque G, Guillaume D \& Dupont J 2015 Expression of adiponectin, chemerin and visfatin in plasma and different tissues during a laying season in turkeys. Reproductive Biology and Endocrinology 13 81. (https://doi. org/10.1186/s12958-015-0081-5)

Dunn IC, Lewis PD, Wilson PW \& Sharp PJ 2003 Acceleration of maturation of $\mathrm{FSH}$ and $\mathrm{LH}$ responses to photostimulation in prepubertal domestic hens by oestrogen. Reproduction 126 217-225. (https://doi. org/10.1530/rep.0.1260217)

Heinz JF, Singh SP, Janowitz U, Hoelker M, Tesfaye D, Schellander K \& Sauerwein H 2015 Characterization of adiponectin concentrations and molecular weight forms in serum, seminal plasma, and ovarian follicular fluid from cattle. Theriogenology 83 326-333. (https://doi.org/10.1016/j. theriogenology.2014.06.030)

Hendricks 3rd GL, Hadley JA, Krzysik-Walker SM, Prabhu KS, VasilatosYounken R \& Ramachandran R 2009 Unique profile of chicken adiponectin, a predominantly heavy molecular weight multimer, and relationship to visceral adiposity. Endocrinology 150 3092-3100. (https://doi.org/10.1210/en.2008-1558)

Itoh M, Suganami T, Satoh N, Tanimoto-Koyama K, Yuan X, Tanaka M, Kawano H, Yano T, Aoe S, Takeya M et al. 2007 Increased adiponectin secretion by highly purified eicosapentaenoic acid in rodent models of obesity and human obese subjects. Arteriosclerosis, Thrombosis, and Vascular Biology 27 1918-1925. (https://doi.org/10.1161/ ATVBAHA.106.136853)

Krzysik-Walker SM, Ocon-Grove OM, Maddineni SB, Hendricks 3rd GL \& Ramachandran R 2007 Identification of calcitonin expression in the chicken ovary: influence of follicular maturation and ovarian steroids. Biology of Reproduction 77 626-635. (https://doi.org/10.1095/ biolreprod.106.054957)

Ledoux S, Campos DB, Lopes FL, Dobias-Goff M, Palin MF \& Murphy BD 2006 Adiponectin induces periovulatory changes in ovarian follicular cells. Endocrinology 147 5178-5186. (https://doi.org/10.1210/en.20060679)

Leszczynski DE, Hagan RC, Rowe SE \& Kummerow FA 1984 Plasma sex hormone and lipid patterns in normal and restricted-ovulator chicken hens. General and Comparative Endocrinology 55 280-288. (https://doi. org/10.1016/0016-6480(84)90113-8)

Liu HK \& Bacon WL 2005 Changes in egg production rate induced by progesterone injection in broiler breeder hens. Poultry Science $\mathbf{8 4}$ 321-327. (https://doi.org/10.1093/ps/84.2.321)

Livak KJ \& Schmittgen TD 2001 Analysis of relative gene expression data using real-time quantitative PCR and the 2(-Delta Delta C(T)) Method. Methods 25 402-408. (https://doi.org/10.1006/meth.2001.1262)

Maddineni S, Metzger S, Ocon O, Hendricks 3rd G \& Ramachandran R 2005 Adiponectin gene is expressed in multiple tissues in the chicken: food deprivation influences adiponectin messenger ribonucleic acid expression. Endocrinology 146 4250-4256. (https://doi.org/10.1210/ en.2005-0254)

Maddineni SR, Ocon-Grove OM, Krzysik-Walker SM, Hendricks 3rd GL \& Ramachandran R 2008 Gonadotropin-inhibitory hormone $(\mathrm{GnIH})$ receptor gene is expressed in the chicken ovary: potential role of GnlH in follicular maturation. Reproduction 135 267-274. (https://doi. org/10.1530/REP-07-0369)

Maillard V, Uzbekova S, Guignot F, Perreau C, Rame C, CoyralCastel S \& Dupont J 2010 Effect of adiponectin on bovine granulosa cell steroidogenesis, oocyte maturation and embryo development. Reproductive Biology and Endocrinology 8 8-23. (https://doi. org/10.1186/1477-7827-8-23)
Maleszka A, Smolinska N, Nitkiewicz A, Kiezun M, Chojnowska K, Dobrzyn K, Szwaczek H \& Kaminski T 2014 Adiponectin expression in the porcine ovary during the oestrous cycle and its effect on ovarian steroidogenesis. International Journal of Endocrinology 2014957076. (https://doi.org/10.1155/2014/957076)

Meng B, Cao Z, Gai Y, Liu M, Gao M, Chen M, Ning Z \& Luan X 2019 Effects of recombinant goose adiponectin on steroid hormone secretion in Huoyan geese ovarian granulosa cells. Animal Reproduction Science 205 34-43. (https://doi.org/10.1016/j.anireprosci.2019.03.019)

O'Connor A, Phelan N, Tun TK, Boran G, Gibney J \& Roche HM 2010 High-molecular-weight adiponectin is selectively reduced in women with polycystic ovary syndrome independent of body mass index and severity of insulin resistance. Journal of Clinical Endocrinology and Metabolism 95 1378-1385. (https://doi.org/10.1210/jc.2009-1557)

Ocon-Grove OM, Maddineni S, Hendricks 3rd GL, Elkin RG, Proudman JA \& Ramachandran R 2007 Pituitary progesterone receptor expression and plasma gonadotrophin concentrations in the reproductively dysfunctional mutant restricted ovulator chicken. Domestic Animal Endocrinology 32 201-215. (https://doi.org/10.1016/j.domaniend.2006.03.003)

Ocon-Grove O, Krzysik-Walker S, Maddineni S, Hendricks G \& Ramachandran R 2008 Adiponectin and its receptors are expressed in the chicken testis: influence of sexual maturation on testicular AdipoR1 and AdipoR2 mRNA abundance. Reproduction 136 627-638. (https:// doi.org/10.1530/REP-07-0446)

Okada-Iwabu M, Yamauchi T, Iwabu M, Honma T, Hamagami K, Matsuda K, Yamaguchi M, Tanabe H, Kimura-Someya T, Shirouzu M et al. 2013 A small-molecule AdipoR agonist for type 2 diabetes and short life in obesity. Nature 503 493-499. (https://doi.org/10.1038/ nature12656)

Oliveira BSP, Costa JAS, Gomes ET, Silva DMF, Torres SM, Monteiro Jr PLJ, Santos Filho AS, Guerra MMP, Carneiro GF, Wischral A et al. 2017 Expression of adiponectin and its receptors (AdipoR1 and AdipoR2) in goat ovary and its effect on oocyte nuclear maturation in vitro. Theriogenology 104 127-133. (https://doi.org/10.1016/j. theriogenology.2017.08.013)

Pierre P, Froment P, Negre D, Rame C, Barateau V, Chabrolle C, Lecomte P \& Dupont J 2009 Role of adiponectin receptors, AdipoR1 and AdipoR2, in the steroidogenesis of the human granulosa tumor cell line, KGN. Human Reproduction 24 2890-2901. (https://doi.org/10.1093/humrep/ dep292)

Ramachandran R, Ocon-Grove OM \& Metzger SL 2007 Molecular cloning and tissue expression of chicken AdipoR1 and AdipoR2 complementary deoxyribonucleic acids. Domestic Animal Endocrinology 33 19-31. (https://doi.org/10.1016/j.domaniend.2006.04.004)

Richards AA, Stephens T, Charlton HK, Jones A, Macdonald GA, Prins JB \& Whitehead JP 2006 Adiponectin multimerization is dependent on conserved lysines in the collagenous domain: evidence for regulation of multimerization by alterations in posttranslational modifications. Molecular Endocrinology 20 1673-1687. (https://doi.org/10.1210/ me.2005-0390)

Roux PP \& Blenis J 2004 ERK and p38 MAPK-activated protein kinases: a family of protein kinases with diverse biological functions. Microbiology and Molecular Biology Reviews 68 320-344. (https://doi.org/10.1128/ MMBR.68.2.320-344.2004)

Singh A \& Krishna A 2012a Effects of adiponectin on ovarian folliculogenesis and steroidogenesis in the vespertilionid bat, Scotophilus heathi. General and Comparative Endocrinology 178 502-510. (https://doi. org/10.1016/j.ygcen.2012.06.027)

Singh A \& Krishna A $2012 b$ Localization of adiponectin and its receptor and its possible roles in the ovary of a vespertilionid bat, Scotophilus heathi. General and Comparative Endocrinology 176 240-251. (https:// doi.org/10.1016/j.ygcen.2012.01.020)

Tiwari A, Ocon-Grove OM, Hadley JA, Giles JR, Johnson PA \& Ramachandran R 2015 Expression of adiponectin and its receptors is altered in epithelial ovarian tumors and ascites-derived ovarian cancer cell lines. International Journal of Gynecological Cancer 25 399-406. (https://doi.org/10.1097/IGC.0000000000000369)

Tsao TS, Murrey HE, Hug C, Lee DH \& Lodish HF 2002 Oligomerization state-dependent activation of NF-kappa B signaling pathway by adipocyte complement-related protein of $30 \mathrm{kDa}$ (Acrp30). Journal of Biological Chemistry 277 29359-29362. (https://doi.org/10.1074/jbc. C200312200) 
Tsao TS, Tomas E, Murrey HE, Hug C, Lee DH, Ruderman NB, Heuser JE \& Lodish HF 2003 Role of disulfide bonds in Acrp30/adiponectin structure and signaling specificity. Different oligomers activate different signal transduction pathways. Journal of Biological Chemistry 278 50810-50817. (https://doi.org/10.1074/jbc.M309469200)

Waki H, Yamauchi T, Kamon J, Ito Y, Uchida S, Kita S, Hara K, Hada Y, Vasseur F, Froguel P et al. 2003 Impaired multimerization of human adiponectin mutants associated with diabetes. Molecular structure and multimer formation of adiponectin. Journal of Biological Chemistry 278 40352-40363. (https://doi.org/10.1074/jbc.M300365200)

Wang Y, Lam KS, Chan L, Chan KW, Lam JB, Lam MC, Hoo RC, Mak WW, Cooper GJ \& Xu A 2006 Post-translational modifications of the four conserved lysine residues within the collagenous domain of adiponectin are required for the formation of its high molecular weight oligomeric complex. Journal of Biological Chemistry 281 16391-16400. (https://doi. org/10.1074/jbc.M513907200)

Yamashita T, Lakota K, Taniguchi T, Yoshizaki A, Sato S, Hong W, Zhou X, Sodin-Semrl S, Fang F, Asano Y et al. 2018 An orally-active adiponectin receptor agonist mitigates cutaneous fibrosis, inflammation and microvascular pathology in a murine model of systemic sclerosis. Scientific Reports 8 11843. (https://doi.org/10.1038/s41598-01829901-w)
Yamauchi T, Kamon J, Minokoshi Y, Ito Y, Waki H, Uchida S, Yamashita S, Noda M, Kita S, Ueki K et al. 2002 Adiponectin stimulates glucose utilization and fatty-acid oxidation by activating AMP-activated protein kinase. Nature Medicine 8 1288-1295. (https://doi.org/10.1038/nm788)

Zhang Y, Zhao J, Li R, Lau WB, Yuan YX, Liang B, Li R, Gao EH, Koch WJ, Ma XL et al. 2015 AdipoRon, the first orally active adiponectin receptor activator, attenuates postischemic myocardial apoptosis through both AMPK-mediated and AMPK-independent signalings. American Journal of Physiology: Endocrinology and Metabolism 309 E275-E282. (https:// doi.org/10.1152/ajpendo.00577.2014)

Zheng J, Sun Z, Liang F, Xu W, Lu J, Shi L, Shao A, Yu J \& Zhang J 2019 AdipoRon attenuates neuroinflammation after intracerebral hemorrhage through AdipoR1-AMPK pathway. Neuroscience 412 116-130. (https:// doi.org/10.1016/j.neuroscience.2019.05.060)

Received 20 October 2019

First decision 29 November 2019

Revised manuscript received 17 December 2019

Accepted 6 January 2020 